\title{
A READING OF “OIL" (JAMES 5:14) IN THE GHANAIAN CHRISTIAN MINISTRY
}

\author{
Daniel Berchie \\ (dberchie@vvu.edu.gh)
}

$\boldsymbol{\&}$

\author{
Elijah Baidoo \\ (eljee12all@gmail.com) \\ Valley View University \\ Oyibi-Accra, Ghana. \\ URL: http://ijourels.org.ng https://dx.doi.org/10.4314/ijrs.v7i1.3
}

\begin{abstract}
This paper sought to examine the meaning and the significance of James 5:14. The place of anointing oil in Christian ministry has taken on new meanings and significance, albeit the traditional views. The anointing oil is being used for exorcism, as a repellant against evil powers, an aid of socio-economic well-being and the like. However, through a lexico-syntactical analysis, it has been concluded that the oil referred to in the passage has a pure medical significance and that prayer of faith, as the worldview of the author, reinforces and accelerates the healing process of the medicinal oil. Therefore, any Christian who shares the worldview of the author can blend prayer of faith and any prescribed medicine to help in a healing process.
\end{abstract}

Keywords: Oil, Ghanaian Christian, Christian ministry, Anointing oil, Bibiani Court

\section{Introduction}

The significance of the oil in James 5:14 has been a concern to scholars and Christians. It is sometimes believed to have some ritualistic effects and both scholars and Christians have attempted to unravel that secret. Experiences had with the oil has indicated that in the Ghanaian Christian ministry, it is strongly held that the oil is used as a catalyst of impacting the 'victim' of evil spirits and liberating him/her from the dominance of the evil. ${ }^{1}$ James 5:14 has been used as the basis for this exercise. Two main views abound in scholarly debates. Some believe that the passage refers to a symbolic revival of the spiritually weak. ${ }^{2}$ Others think that the physically sick is symbolically healed with oil cum prayer. In a similar vein, it is taught that the oil has a medicinal effect on the sick. ${ }^{3}$ The debates surround the meaning of astheneo "to be weak" "to be sick," or "to be in need" 4 as a reference to either spiritual weakness or physical sickness. In this study, a reading of this passage is in order to spell out the significance of the oil in our contemporary reading. The study also aims at suggesting a contextual application of the significance of anointing oil in the Ghanaian Christian Ministry. 
The issue has got to do with the meaning of the astheneo (the physically sick or spiritually weak) and aleiphō "to anoint with oil or perfume" in James 5:14. Does astheneō refer to the physical sickness or spiritual weakness? Also, does aleipho have a symbolic or physical effect? To this end, an exegetical approach, a lexico-syntactical analysis is employed. The study attempts to address these concerns through exegetical approach as they relate to the use of oil in Ghanaian Christian ministry. Apart from the introduction and the conclusion, the study is presented in six phases, namely, (1) occasion for writing James, (2) Literary Theme(s) of James, (3) Limit and Genre of James 5:14, (4) Provisional Translation of James 5:14, (5) Reading James 5:14, and (6) The Significance of the Oil in Ghanaian Christian ministry.

\section{Occasion for Writing James}

James writes to Jewish Christians who were scattered abroad probably as a result of persecution in Jerusalem (James 1:2-3; 2:2, 21; cf. Acts 1:1; James $2: 21) .{ }^{6}$ As a prominent leader of the early Christian community in the apostolic period, he felt obliged to encourage the dispersed Jewish believers to press on in the faith and also share a balanced attitude of Christian living. The current situation of the intended audience is vaguely glimpsed from the letter. On the one hand, what seems clear is the authority with which the author writes. As observed by a number of scholars, the author seems to have held a significant and a well-known position in the early church to have been able to write authoritatively (cf. Acts 12:17; 15:6-29; 21:18; Gal 1:18,19; 2:9, 12). ${ }^{7}$ On the other hand, there is no clear evidence from the epistle that James knew the prevailing situation of the audience.

However, the author seems to assume audience who had regular meetings for worship with church leadership in place, planned for daily activities, and engaged in businesses for living $(2: 2-13 ; 4: 13-17 ; 5: 1-12,14)$. The literary theme(s), as presented below, used by the author seems to betray an author who felt responsible to share some general and practical counsels with the scattered Jewish Christians so that they could regulate their Christian ethical decisions in anticipation of the Parousia. In short, James writes to shape a balanced perspective of the essence of pure religion, emphasizing evidence of faith in Christ Jesus through good deeds in the face of any situation $(1: 27){ }^{8}$

\section{Literary Theme(s) of James}

The Letter of James is seen as a catholic epistle owing to its wider, though specific intended, geographical audience. Though an epistle, it takes the form of an exhortative homily. ${ }^{9}$ It uses more imperatival statements than any NT document. ${ }^{10}$ James is noted for bridging the gap between faith in Christ Jesus and works (good deeds), using these imperatives. ${ }^{11}$

James may be seen as one featuring topical homily, brief and different themes are lumped together to address different concerns of the author in light of 
his overarching theme of faith and works in concert. ${ }^{12}$ The overarching theme of demonstration of faith through good deeds seems to permeate the epistle as follows: believers in trial should exercise patience (James 1:2-4); the one who lacks wisdom should ask for wisdom from God with faith (vv. 5-8); the poor should rejoice over the oppressive rich because of the inevitable end of the rich (vv. 9-11); believers are urged to endure temptation for there is an unimaginable reward awaiting (vv. 12-20); believers should be doers of the word not only hearers (vv. 21-27); believers should respect all persons irrespective of their financial standings (2:1-13); faith and works should go together (vv. 14-26); believers should be careful of an unbridled tongue (3:1-18); believers should be watchful of their lust and their association with the world (4:1-6). believers should learn to be humble (vv. 7-10); believers should speak well of each other (vv. 11-12); believers should guard against boasting and let God lead them (vv. 13-17); the miserable end of the oppressive rich of the poor is painted to give hope to the poor to forge on $(5: 1-6)$; believers should exercise patience as they wait for the Parousia (vv. 7-8); believers should not bear grudges against one another (v. 9); believers should endure suffering as Job did for there is a reward awaiting (vv. 10-11); believers should be honest in their dealings (v. 12); believers should pray during suffering for divine intervention (vv. 13-18); and a sinning believer should appreciate corrections from a fellow believer (vv. 19-20).

The use of imperatives and the topical presentations of different and unrelated subjects seem to demonstrate that it took someone in authority to demand obedience towards God. The author may have known them as "the twelve tribes scattered among the nations" (James 1:1 NIV). However, the lack of any personal or informed knowledge of the present situation of the audiences suggests that the author intended to give general admonitions to guide their faith in their new communities. In any event, practical Christianity is heightened in James. This view of practical Christianity may provide context for understanding $5: 14$, as demonstrated below. With this, we now turn to the limit and the genre of James 5:14.

\section{Limit and Genre of James 5:14}

James 5:1-6 focuses on the miserable end of the oppression of the rich. Vv. 7-12 present the need for the poor believers to endure and live a responsible life as they wait for the Parousia. V. 12 particularly concludes this unit with the expression pro pantōn de "but above all." V. 13 introduces a new topic with a singular adjective indefinite pronoun tis "anyone" which deviates from the plural addressees adelphoi "brothers" in v. 12. The syntax of the structure in vv. 13-18 betrays an implicit first class condition (for example, see kakopathei tis "is anyone/someone suffering"....proseuchestho "let him/her pray". ${ }^{13}$ The use of 
plural address adelphoi in v. 19 and a third class condition (for example, see ean tis "if anyone"... planēthē "should/may wander"... ginōsketō "let him/her know") in vv. 19-20 make vv. 13-18 a literary unit.

The word proseuchomai "I pray" and its related lexemes (euche "prayer" euchomai "he prays" and deēsis "prayer") occur seven times in vv. 13-18. The idea of appealing to God a supernatural being for an intervention seems to make this unit cultic.

The genre of James 5:14 as found in vv. 13-18 seems cultic. This means that certain rituals are prescribed to be used to address the concerns of potential sufferers. These rituals underscore a conscious and an intimate relationship between believers and the supernatural. In a word, v. 14 may be understood in vv. 13-18 which is a cultic (worship) setting. The next section is the provisional translation of the passage understudy.

\section{Translation of James 5:14}

The provisional translation of James 5:14 is as follows:

asthenei tis en humin,

proskalesasthō tous presbuterous tēs

ekklēsias

kai proseuzasthōsan ep' auton

aleipsantes auton elaiō

ev tō onomati tou kuriou. (if someone is weak/sick among you,)

(let him call for the elders of the church)

(and let them pray on him)

(while anointing him with oil)

(in the name of the Lord). ${ }^{14}$

With this tentative rendering of the passage, we consider its meaning in the following section.

\section{Reading of James 5:14}

James 5:13a makes clear that when a believer suffers hardship/misfortune (kakopathei) [2 Tim 2:9; 4:5], he/she should pray. Prayer for divine intervention is the answer for suffering. Probably the divine intervention here is the sustenance of the sufferer while waiting patiently for the Parousia (see vv. 4-6, 7-12). Verse 13b indicates that when a believer is cheerful, he/she should sing praises.

The condition of the believer in v. 13b is different from that of v. 13a. In these varied instances, individuals should follow their respective rituals without the interventions of their community of faith. It may be noted that the suffering of hardship and being cheerful are physical realities

In v. 14a, a weak/sick believer should call for the elders of the church to offer prayer on him/her and anoint him/her with oil in the name of the Lord. A believer in such a condition should take the passive role of applying the rituals associated with his/her restoration. Broadly speaking, the Greek asthenē can 
have both literal and figurative meanings. ${ }^{15}$ Literally, it can mean 'physical sickness' (Matt 10:8; 25:39; John 11:1ff; Acts 9:37; Phil 2:26f.) In figurative sense, it can be used in reference to weak in faith (Rom 4:19; 14:1f; 2 Cor 11:29.). As noted earlier, the suffering of hardship and being cheerful are physical realities in James 5:13.

In v. 15 , the Greek kamnō, literally "to grow weary" or "to be sick" is used in reference to the asthenē in v. 14a. Kamno is used both in classical and koine periods in reference to a physical weakness as a result of either physical working or sickness. ${ }^{16}$ In the NT, outside James, it is used in a sense of 'being discouraged' (Rev 2:3; Heb 12:3).

A survey of the use of aleipho can shed some light on the meaning of asthenēo plus kamnō. In ancient (biblical) times, objects and human beings were anointed (aleiphō) with oil. Religious objects such as the tabernacle and its entirety-such as the altar of burnt offering and the basin with its stand---are anointed with oil at the time of dedication (Exod 40:9-11). Jacob anointed the rock at Bethel on which he had slept in connection with a vow (Gen 31:13; cf. 28:19). Wafers (thin cakes) were ritually anointed with oil probably for preservation purposes (Exod 29:2; Lev 2:4; 7:12; Num 6:15).

In all these instances, the Hebrew māšah "to rub" is used in a technical sense of setting apart for religious use. ${ }^{17}$ With the exception of Gen 31:13 where the LXX translates māšah as aleiphō "to anoint," the rest are rendered as chriō "to anoint." ${ }^{18}$ Probably, chriō is used to highlight the prescription of Adonai as against human descriptive activity.

It is interesting to note that Prophet Isaiah understood anointing ( $m \bar{a} \bar{s} a h)$ of God as empowerment to perform a particular spiritual task (Isa 61:1). The use of chriō may carry a symbolic meaning of specialness and empowerment. In reference to people who were anointed for undertaking special responsibilities, $m \bar{a} s ̌ a h$ is used. Priests (Exod 30:30), kings (1 Sam 16:12-13; Ps 89:20), and a prophet (1 Kings 19:16) fit this category. With the exception of the anointing of the sons of Aaron (Exod 40:15; Num 3:3), ${ }^{19}$ the LXX renders $m \bar{a} \check{s} a h$ in these contexts as chriō.

Apart from these religious anointing practices, people used oil to anoint themselves for beautification, soothing the skin, and healing. The Hebrew for such usage is sîk "to grease oneself with oil" (Ruth 3:3; 2 Sam. 12:20; 2 Sam. 14:2; 2 Kings. 4:2; 2 Chr. 28:15; Est. 2:12; Jdt. 16:7; Mic. 6:15; Dan. 10:3) ${ }^{20}$ In all these instances, the LXX translates sûk as aleiphō.

In the NT, aleipho is used nine times. About half of the usage has to do with the physical greasing of the body of Jesus (Mark 16:1; Luke 7:38, 46; John 12:3). Those who fast are to anoint (grease) their head and wash their face to look fresh and genuine (Matt 6:16-17; cf. 2 Sam 12:20). ${ }^{21}$

In Mark 6:13, the disciples cast out many demons and anointed the sick with oil and healed them. These activities were performed in the context of the gospel proclamation where the name of Jesus was invoked. 
In contrast, the Greek chrio occurs only five times in the NT. Four of the uses refer to the anointing of Jesus as the only one appointed by God with the empowerment of the Holy Spirit to preach good news to the poor (Luke. 4:18; Acts 4:27; Acts 10:38; Heb. 1:9). Paul used the term in the same vein in reference to his ministry (2 Cor. 1:21).

Believers have also received anointing (chrisma) of God which remains in them and teaches them all things. Here, the Holy Spirit may be intended as the anointing which remains in believers (1 John. 2:20, 27). In essence, aleiphō appears to convey a consistent physical application with visible results whereas chriō presents a symbolic picture of assigning responsibility and empowerment.

Per the practice in the NT, the weak in faith are usually strengthened with teaching and/or prayer (Luke 22:31-32; 1 Cor 3:1-4; Heb 6:1-3; 10:23-25; 1 Pet 5:10; Rev 3:2). No mention is made of aleipho "to anoint," with oil as a symbolic gesture of empowering the weak in faith or sufferer of hardship.

It can, therefore, be said that astheneō refers to physical sickness which would need physical anointing for a physical healing. ${ }^{22}$ The overarching theme of James reinforces this understanding in that faith and works must blend to achieve desired results. From the perspective of James, the supernatural influence is important for physical healing of physical sickness.

Per the grammar of v. $14 \mathrm{~b}$ and c, the oil is applied to the sick while prayer is being offered in the name of the Lord. James uses aorist tense for both the imperative and the participle to express the contemporaneity of the acts of praying and smearing of the oil. ${ }^{23}$ This suggests a simultaneous supernatural influence on the physical medicine in the healing process. In other words, without God, physical medicine has little or no effect. Prayer of faith is deemed as the ultimate catalyst for achieving the desired result in v. 15 . In the context of worship, it is the prayer of faith that heals not the medicinal oil. ${ }^{24}$

Verse $15 \mathrm{~b}$ offers another supporting insight. A third class condition is used to express the belief that healing may be connected to forgiveness of sins. ${ }^{25}$ This belief was a thought-world of the Jews. The syntax of $15 \mathrm{~b}$ does not suggest that the sickness mentioned in v. 14 may have been caused by sin. Rather, $15 \mathrm{~b}$ suggests, in the event of sickness afflicted by sin, prayer of faith of elders can also yield much. Ill-health was generally linked with $\sin$ in the Jewish worldview (cf. Job 4-37; Deut 28:58-60; Num 12:13-15; 21:4-9; Ps. 38; 1 Sam 4:106:18; especially John 9:2-3). ${ }^{26}$ James entertains the possibility that if the sickness is caused by sin, after showing repentance and receiving the prayer of faith, healing is likely to take place. Therefore, prayer of faith, sincere repentance of sins of the sick (if committed), and medicinal oil offered by the elders in this worship setting should bring healing to the sick.

Therefore, James 5:14 may be rendered as follow: "If someone is physically sick among you, let him/her call for the elders of the church and let them pray on him/her while anointing him/her with oil in the name of the Lord." 
Having arrived at this understanding, we focus our attention on the significance of the oil in Ghanaian Christian Ministry.

\section{Significance of the Oil in Ghanaian Christian Ministry}

Oils from Sesame, nut, radish, rose, and olive were used in ancient times. For instance, Sesame was common in Babylon while nut, radish, and olive were used by people of Medea, Alexandria and Israel respectively (b. Shab. 26a; $b$. Ned. 53a). Olive oil seems to have been used predominantly by the Jews in Palestine. Olive plant is quite adaptable to the Mediterranean climate. ${ }^{27}$ What kind of oil did James have in mind when he used the word aleipho in 5:14?

The anointing oil prescribed for the consecration of the priests consisted of " 500 shekels of liquid myrrh, half as much (that is, 250 shekels) of fragrant cinnamon, 250 shekels of fragrant calamus,500 shekels of cassia--all according to the sanctuary shekel--and a hin of olive oil" (Exo 30:23-24 NIV). According to divine injunction, this fragrant blend of sacred oil should only be used for consecrating priests but not for personal use (vv.31-33). A breech of this injunction amounted to unpardonable sin whose punishment was death. Since James wrote to a Jewish Christian community, he would not have recommended such sacred oil for non-priestly use.

Since the elders in James 5:14 were to anoint the body of the sick, it is clear that the ointment was not meant to be taken orally. By the use of the indefinite pronoun tis (anyone, someone), no priest was intended. And the context makes clear that the ointment to be used was for medicinal purposes. Based on the foregoing, the ointment used had healing properties. The author, being a Jew and a resident of Palestine, might have intended olive oil with other ingredients since olive was predominantly common in Palestine. But it should be mentioned that he did not give any command as to the specific kind of oil to be used.

When olive oil was used for medicinal purposes, it was often used with other ingredients (cf. Luke 10:34). However, since the Jewish audience were scattered abroad, they might have used any kind of oil available to them, which had medicinal potency as used with other ingredients (James 1:1). This observation may find its parallel in the protest against the exclusive use of olive oil as fuel for the household lamps on the Sabbath among Jews scattered abroad (b. Shab. 26a). It can, therefore, be deduced that the audience of James might have used any kind of oil available to them and known to have had medicinal potency. Besides the debate on the kind of oil used, the emphasis of James seems to have been heavily placed on prayer of faith which actually heals. It can be surmised that any medication administered on a sick person with prayer of faith may evince some positive results. 
Olive oil is applied to almost every unfortunate situation by Christian ministers in Ghanaian Christian Services. They evoke a symbolic significance of the oil for all sorts of human problems, including physical sicknesses in Ghanaian setting. Some ministers have gone to the extent of prescribing the brand of olive oil to be used for divine intervention in one's life. The kinds of olive oil sold at the church premises seem to be more expensive than the same kinds on the market. ${ }^{28}$

With evidence from the preceding paragraph, a survey done on the use of the anointing oil in the Ghanaian Christian ministry indicates that the oil is used as a catalyst of impacting the 'victim' of evil spirits and liberating him/her from the dominance of the evil. In essence, the symbolic use of the oil is taught and believed in the Ghanaian Christian Ministry. For example, an evangelist was arrested by the Bibiani Court in the Western Region of Ghana on this symbolic understanding and abuse of the oil leading to sexual assort of certain lady. "Dadzie collected from the victim $\mathrm{GH} \phi 13$ to purchase anointing oil to ward off the evil spirits tormenting her life. The accused called the lady on her cell phone on March 23, to come for the oil and when she went, the evangelist followed her to her room. There he grabbed her and sexually assaulted her, the prosecutor said." ${ }^{29}$ With this understanding of the symbolic use of the oil, pastors and members are taught and made to believe that anointing oil is used in the solution of all problems, being physical sickness or spiritual harassment of any sort. For example, it is used on the body of the witch in a way of exorcising him or her. ${ }^{30}$

The oil is also used as a catalyst to speed up the death of someone who is suffering and it appears he or she awaits eminent death. ${ }^{31}$ Pastors and Church members believe that this symbolic use of the oil will bring instant healing or death according to God's will. Also, someone who reports to be having "sex" in dreams is also anointed as the effective way to ward off the evil spirit engaged in "spiritual marriages" with such individuals. ${ }^{32}$ In sum, pertaining to the symbolic use of the oil, Ghanaian Christians believe that the oil has effective ritual and spiritual impact sometimes even without prayer. It is evident that the oil is perceived to be very powerful even if prayer is not said while applying it on the individuals in the alleviation of their problems. This appears to be contradicting what is given by James in 5:14.

This practice appears to be an abuse on the significance of oil in light of the injunction given by James in 5:14. The symbolic use of the oil in the Ghanaian churches appears to be a deviation from the implication and the application of James 5:14 regarding the oil. James appears to be recommending the use of the oil for medicinal purposes backed by a prayer of faith. Therefore, the use of the olive to solve all "problems" in the Christian ministry appears to be 
doctrinally fraught with difficulties and also misleading per the context of James 5:13-18.

The problem in the Ghanaian Christian ministry concerning the use of the olive is the fact that church members are made to buy the olive oil very expensive than the price on the market. The faith appears to have been shifted to the application of the oil on the body of the victim with less emphasis on the prayer of faith in the name of the Lord. In essence, the attention of members has been drawn from the focus of a fervent prayer of faith in the name of the Lord that actually does the healing. Should members be taught the significance of the oil in James 5:14, it will help them to consider seeking medical help when they are physically sick while they seek the face of God in the healing process by a prayer of faith. The "weak" or the "sick" in James appears to refer to physical weakness or sickness and not spiritual weakness. The oil, therefore, appears to have medicinal significance and not to be construed symbolically.

Assuming James meant only medicinal oil, there are oils in Ghana with healing properties, namely, coconut, shea butter, palm kernel and the like. However, different kinds of olive oil are imported into the country while native oils are unexplored and underused. The attitude towards olive oil in Ghanaian Christian ministry seems to cast the ministry into a kernel of Judeo-Christian colonial husk. ${ }^{33}$ Thus, this study seeks to suggest a fresh understanding on the use of the oil that James recommended a medicine to be used by the sick that was intended to be backed by prayer of faith in Jesus.

Oil in James is applied while prayer is offered. The medicinal oil is used in the context of healing a physical sickness. The same is found in Mark 6:13: The oil is applied to the sick not the demon possessed. It is suggested that a Christian sharing the worldview of James can blend prayer of faith and physical medicine to help in a healing process. But if it happens that the sick has committed any sin that has resulted in the sickness, he/she must confess to be healed.

\section{Conclusion}

The main objective of this study was to exegetically read James 5:14 as it relates to the significance of the anointing oil in the Ghanaian Christian ministry. The use of anointing oil, that is, olive oil, in Ghanaian Christian ministry varies appealing to James 5:14 as primarily biblical support. However, based on the foregoing, it has been observed that the passage may speak of a contemporaneous application of any medicinal oil/medicine and prayer of faith by the leaders of the community of faith. And if $\sin$ is considered as the cause of the sickness, a sincere confession would help in the healing process. It is in this light that anointing oil can be significantly applied in Ghanaian Christian Ministry. 


\section{Notes and References}

1 See the work of Roland Owusu Ansah, "The Usage Of Anointing Oil In Some Charismatic and Neo-Prophetic Churches in Kumasi In The Context Of Leviticus 8:1-12, And James 5:14-15," A Thesis Submitted to The School of Graduate Studies, for the Degree of Master Of Philosophy in Religious Studies (Kwame Nkrumah University of Science and Technology, Kumasi, Ghana, August 2011), 104-151.

2 Ralph P. Martin, James, Word Biblical Commentary, vol. 48 (Nashville, TN: Thomas Nelson, 2002), 207-209; Craig S. Keener, The IVP Bible Commentary(Downers Grove, Illinois: Intervarsity Press, 1993), 73; D. R. Hayden, "Calling the Elders to Pray" Bibliotheca Sacra 138 (1981), 258-66; C. Pickar, "Is anyone sick among you?" (1945), 65-74; Tokumboh Adeyemo, ed., Africa Bible Commentary (Nairobi, Kenya: WordAlive, 2006), 1516; Robert Jamieson, A. R. Fausset and David Brown, eds., Commentary on the whole Bible (Grand Rapids, Michigan: Zondervan, 1979), 1459-60.

3 W. Harold Mare, New Testament Background Commentary: A New Dictionary of Words, Phrases and Situations in Bible Order (Scotland: Mentor, 2004), 390; Kenneth L. Baker and John R. Kohlenberger III, Zondervan NIV Bible Commentary: New Testament, vol. 2 (Grand Rapids, Michigan: Zondervan, 1999), 1038. See also Donald W. Burdick, "James," in The Expositor's Bible Commentary, vol.12, ed. Frank E. Gaebelein (Grand Rapids, Michigan: Zondervan, 1981), 204; Douglas J. Moo, James, in Zondervan Illustrated Bible Background Commentary, ed., Clint E. Arnold, vol. 4 (Grand Rapids, Michigan: Zondervan, 2002), 116117; "Anointing" (James 5:14), The Seventh-day Adventist Bible Commentary (SDABC), rev. ed., ed. Francis D. Nichol (Washington DC: Review \& Herald, 1976-80), 7:540-41.

4 Joseph Henry Thayer, A Greek-English Lexicon of the New Testament, based on Grimme's Wilke Clovis Novi Testamenti (Grand Rapids, MI: Baker, 1977), s.v. astheneō.

5 Thayer, s.v. aleiphō.

6 D. A. Carson, Douglas J. Moo, and Leon Morris, An Introduction to the New Testament (Manila, Philippines: OMF Literature Inc., 1992), 414-415; Burdick, 162-163.

7 Burdick, 162.

8 Carson, Moo, Morris, 418.

9 Bruce M. Metzger, The New Testament: Its Background, Growth, and Content, 3d ed. (Nashville, TN: Abingdon, 2003), 287-288; Carson, Moo, and Morris, 416.

10 Carson, Moo, and Morris, 415. 
11 Sophie Laws, "James, Epistle of." In The Anchor Bible Dictionary $(A B D)$,vol. 3. ed. David Noel Freedman (New York: Doubleday, 1992), 626; Carson, Moo, and Morris, 418-419.

12 So also Carson, Moo, and Morris, 416.

13 In the Greek, there is no punctuation for the question mark in other English translations. This punctuation assumes the author's knowledge of a sick person among the 'scattered audience'. The structure of 5:14 seems to suggest some conditionality. For instance, when an indefinite pronoun tis (anyone, someone) is used with an indicative mood with a conditional particle $e i$ (if, since) and a verb in an imperative mood follows, the structure is a conditional structure. This pattern is common in the NT (for example, see Matt 16:24; Mark 4:23; 8:34; 1 Cor 14:37; 1 Tim 5:4; James 1:5). However, in James 5:13,14, minus a conditional particle $e i$, the structure is intact. The indefinite pronoun is used substantively. And considering the fact that the author was writing to a dispersed Christian community that he was not very much aware of their very pressing situations, it would not be out of place to render vv. 13 and 14 as first class conditional statements. It would then mean that the substantive use of tis in v. 14 plus a verb in an indicative mood (asthenei "he is sick/weak") can function as a protasis while a verb in an imperative mood (proskalesasthō "let him call") becomes the apodosis. This conditional statement expresses an assumed reality. This means that the author in this case would have expected the believers in Diaspora to adhere to his prescription for healing anyone with astheneo "to be weak or sick."

14 A tentative rendering of astheneo as either weak or sick is adopted here until a definite conclusion is reached.

15 Walter Bauer, A Greek-English Lexicon of the New Testament and Other Early Christian Literature (BAGD), trans. and adapted by William F. Arndt and F. Wilbur Gingrich, 2nd ed., rev. and augmented by F. Wilbur Gingrich and Frederick W. Danker (1979), s.v. astheneō.

16 Henry G. Liddell and Robert Scott, A Greek-English Lexicon, 9th ed. rev. and augmented by Henry Stuart Jones and Roderick (1940), s.v. kamnō.

17 Francis Brown with S. R. Driver and Charles A. Briggs, A Hebrew and English Lexicon of the Old Testament with an Appendix Containing the Biblical Aramaic (BDB), based on the lexicon of William Gesenius (1952), s.v. $m \bar{a} s ̌ a h$.

18 Thayer, s.v. chriō.

19 The LXX renders māša in reference to the anointing of Aaron in Exod 40:13 as chriō (see also $28: 41 ; 30: 30$ ).

20 Brown, Driver, and Briggs, $B D B$, s.v. sûk.

21 Bauer, BAGD, s.v.aleiphō 
22 See also J. P. Louw, and E. A. Nida, Greek-English Lexicon of the New Testament Based on Semantic Domains, 2 vols. (New York: United Bible Society, 1988), s.v. aleiphō

23 Daniel B. Wallace, Greek Grammar beyond the Basics (Grand Rapids: Zondervan, 1996), 624-625.

24 Laws, 626.

25 See Wallace, The Basics of New Testament Syntax: An Intermediate Greek Grammar, (Grand Rapids, MI: Zondervan, 2000), 313.

26 Howard Clark Kee, "Medicine and Healing," in $A B D$,vol. 4. 659-664.

27 Warren J. Heard, "Olives, Mount of," in $A B D$, vol. 4. 13-15.

28 Ansah, 104-151;“Anointing Oil Now Sells At 200 Ghana Cedis,” accessed from http://www.ghanajuice.com/3180; accessed on 23/11/15.

29 "Bibiani Court Issues bench Warrant for the arrest of evangelist", accessed from

http://www.ghanaweb.com/GhanaHomePage/SportsArchive/artikel.php?ID $=175245$; accessed on 15/02/17.

30 Lydia Aziato, Philippa N. A Odai and Cephas N. Omenyo, "Religious beliefs and practices in Pregnancy and Labor: an Inductive Qualitative Study among Post-Partum Women in Ghana," accessed from https://www.ncbi.nlm.nih.gov/pmc/articles/PMC4895969; on 15/012/17. In this study, it was found out that Pastors use spiritual interventions in pregnancy including prayer and revelations, reversing negative dreams, laying of hands and anointing women. The study also revealed that Religious artefacts used in pregnancy and labour were anointing oil, blessed water, sticker, blessed white handkerchief, blessed sand, Bible and Rosary. Some women are taught and made to believe that any spiritual intervention could be made effective by prayed over olive oil and anointing themselves. The areas of the body anointed included the forehead, head, abdomen and feet.

31 Ansah, "The Usage of Anointing Oil in some Charismatic and NeoProphetic Churches in Kumasi In The Context Of Leviticus 8:1-12, And James 5:14-15," 146.

32 Ansah, "The Usage Of Anointing Oil...".

33 Seventh-day Adventist Minister's Handbook, The General Conference of the Seventh-day of Adventist Ministerial Association (Silver-Spring, Maryland, USA: Review \& Herald, 2009), 192-194, recommends olive oil for physical healing ministry. It further presents a consistent approach of Christ and the early church Christians in casting out demons by commanding evil spirits to leave. This is the teaching of the Seventh-day Adventist church. However, when it comes to practice in ministry, based on my own experience, a number of the Gospel ministers have been using specifically olive oil in deliverance services and for any other human problems. Such practice doe 
not only ridicule the sanity of biblical teaching but also betrays a picturesque disharmony of practice in ministry. Baptism of Jesus took place in river Jordan. Yet the early Christians baptized people who accepted the faith in waters other than Jordan's. The essence of literal water baptism is that it should take place where water may be available. The same can be said of the ritual of the Lord's Supper. It is important for Bible readers to appreciate the use of essence, form and meanings of biblical mandates in their applications today. 


\section{BLANK}

